\title{
UNDERSTANDING DIFFERENT GRAPHIC LEGENDS INFORMATION IN THE PROCESS OF LEARNING
}

\author{
Ivana Žganjar, Dorotea Kovačević, Maja Brozović
}

Original scientific paper Students' perception of graphically shaped information is in large part determined by the design of the depicted information. By choosing the appropriate graphical elements one can facilitate easier comprehension of a system which is displaying new contents to the students. For the purpose of this study, a landscape architecture site plan was used with three different ways of depicting a legend (symbols, numerals, strokes). Quantitative data (response time and number of fixations) on the visual perception of 50 students studying the landscape architecture site plan was gathered using eye-tracker technology. The participants' task was to find the correct name of the plant displayed on the site plan by using the legend. The results showed that students interpret the graphical information more correctly when they are depicted with numbers. The students required more time and needed to pay closer attention to the planting plan when the information was depicted with strokes.

Keywords: graphic design; legend; students; visual perception

\section{Razumijevanje informacija grafički različito oblikovanih legendi u procesu učenja}

Izvorni znanstveni članak Način na koji studenti percipiraju grafički oblikovane informacije u velikoj je mjeri određen dizajnom prikazanih informacija. Odabirom odgovarajućih grafičkih elemenata moguće je olakšati snalaženje u sustavu koji studentima prikazuje nove sadržaje. U ovoj studiji rabljen je tlocrtni prikaz krajobraznog uređenja s tri različita načina prikazivanja legende (simboli, brojevi, linije). Uporabom eye-tracker tehnologije omogućeni su kvantitativni podaci (vrijeme uočavanja i broj fiksacija) o vizualnoj percepciji 50 studenata tijekom promatranja plana krajobraznog uređenja. Zadatak ispitanika bio je da, rabeći legendu, pronađu točan naziv biljne vrste prikazane u planu uređenja. Rezultati ukazuju da studenti točnije interpretiraju grafički oblikovane informacije kada se one označavaju pomoću brojki. Osim toga, ustanovljeno je da je studentima potrebno više pažnje i vremena za snalaženje u planu sadnje ukoliko su informacije prikazane pomoću linija.

Ključne riječi: grafički dizajn; legenda; percepcija; studenti

\section{Introduction}

Landscape architecture represents the infrastructure of a highly complex function whose social role is to solve important spatial problems on all levels, from local, to regional and national. It encompasses a wide range of disciplines, such as geology, pedology, botany, ecology, agrarian and urban sociology, as well as economics, different technical skills, urban, regional and landscape planning, protecting the environment and finally, shaping a wide range of landscape objects. Landscape architecture's identity is expressed in many fields. Landscape architecture solves those spatial social problems that are left out of reach of other functions and activities. Its subject, the landscape, determines it only partially, since many other fields of study deal with landscape but with different goals and mostly through observation; geography for scientific knowledge, agriculture for income purposes, forestry for the optimization of forest farming, urban development in finding the optimal use of space etc. Landscape architecture's activities are geared toward creating and protecting new landscape structures. Among all of the design disciplines, only landscape architecture uses natural materials, such as, earth, plants, water, and a wide variety of other, especially inorganic, materials along with using methods of processing materials into socially developed landscape artefacts. Landscape architecture uses its own vocabulary and design syntax, it has developed specific types of symbols to represent natural, spiritual manifestations through planning and designing activities. The result of the design is the structural definition of the landscape by specifying the position of the elements, their size, shape, texture, colour, plant types, construction materials etc. in accordance with landscape architecture plans [1].

The characteristics of the wide range of disciplines that deal with landscape, point to a need for communication among experts, which is achieved by the schematics and description of the laid out plan. It is expected that the results of this case study will be applicable to a wider audience with an emphasis on the implementation in the syllabus and the development of the curriculum, so that young experts could implement new-found knowledge in their future work.

A landscape architecture plan, suitable to the microclimate, ecological and topographic characteristics of the environment, conditions of the location and programming demands, deals with all of the elements of open (outdoor) space design in a functional and formed way. The purpose of a landscape architecture project is to organize all landscape structures in and around populated areas in an effort to contribute to the planned use of space, a more efficient protection and to the better quality of landscape design. Architectural design of landscape architecture encompasses all works relating to the construction of new buildings, reconstructions and maintenance. Architectural design of landscape architecture consists of eight basic phases of development: reviewing the task, concept solution, concept design, location permit, main project, construction permit, final project, cost estimate. The planting plan for plant material, differentiating between newly planned and existing (which fits into the new solution) vegetation, in the corresponding scale for 
construction, is part of the final project and is chosen as the basis for the case study [2].

The choice of patterns and plans in this case study was done under the guidance of landscape architecture and design experts, and it was based on research which showed that this approach had a positive effect on learning and knowledge application [3]. This way, students exercise their design skills and gain new insights into professional design mechanisms. A professional designer's influence provides them with the confidence to use their full potential in solving future problems in class or in the workplace.

In enhancing the intelligibility of the landscape plan, we see the importance of the choice of pattern selection.

Drawing and its product, the finished plan, fall into a very wide field of graphical expression extremely connected with technique, approach and content, as can be seen in technical drawings in construction, architecture, landscape architecture, engineering, computer aided design drawings (CAD) and computer graphics [4]. It is widely accepted in the engineering community that sketching and the sketch are a crucial part of the design process. That is why they are recommended for developing spatial capabilities, but they are also recognized as a way to boost visual imagination and creativity. Various tools are used in classical technical drawing, adequate drawing paper sizes, scales, lines, technical lettering for the descriptions of technical drawings. The drawings are adequately organized and fitted with a title block and parts list for which CAD systems are used. It is important to emphasize the importance of sketching regardless of the wide use of CAD systems in the process of graphic design, shaping and planning [5].

Title blocks and parts lists are used to enter the basic information about the drawing, necessary for its identification and application. Title blocks and parts lists are usually drawn in the lower right corner of the drawing regardless of its size. The shape and content of the title block are not uniformly set. The title block is drawn in the lower right corner of the format when it is set to landscape, and with its whole width at the bottom of the format when it is set to portrait. As a rule it contains information necessary for the identification and understanding of the drawing's contents. The parts list is usually drawn above the title block, in case there is not enough space, it can be drawn in another area of the drawing format. All parts of the assembly drawing and all characteristic information about the work are written in the parts list. The parts list is a part of the drawing's technical documentation. It has the shape of a table containing information essential to the correct use of the drawing which is not entered in the title block. Its shape and content are not uniformly set. The parts list can be set on the drawing itself or separately. If it is set on the drawing it is placed above the title block and connected to it. The parts list is filled from the top down [4]. All information relating to the shown object is entered in the parts list, such as: object title, what it belongs to, its component parts and the characteristics of these parts; all of the information relating to the drawing, such as: the scale or scales of the drawing, drawing number, group number to which the drawing belongs, the date of drawing, possible drawing revisions, the name of the designer and persons who inspected and approved of the drawing; and lastly the information relating to the work place in which the drawing was made, as well as the information for whom it was made [6]. If need be, the title block and parts list can be adjusted to the needs of a company which results in great differences among companies. The difference is shown in the size of the parts list, the number and placement of the information [4]. Separate A4 format parts lists are being used in recent times for various reasons such as, easier printing, strategic reasons, easier revisions etc. They are an annex to the assembly drawing and usually carry their title block number [7].

A necessary prerequisite for optimal work on a project, production, use and maintenance of the product, object or system are the coordinated efforts of the various collaborators. To achieve this, they have to find a way to share certain information that is, to communicate. Because of the nature of information in technical matters it is necessary to enable the right and unambiguous transfer of certain information among collaborators regardless of time, space and the relationships between them. This is possible only by defining and applying adequate norms and rules for presentations and information sharing.

Graphic communication or imagery is an especially important way of showing and transferring information in technical matters. Imagery is essentially a way of storing and transferring information, that is, a communications medium. In terms of capacity, i.e. the amount of information stored or transferred, an image by far surpasses speech or text.

To present complex clusters of information in an adequate and intelligible way, they need to be organized in logical and contextual units on the basis of their mutual correlations. A basic information unit which contains a mutually connected logical set of information on a technical device or system is called a document. A document can contain information presented by imagery or in a textual form. A set of all relevant documents regarding an object or system is known as technical documentation. The complete documentation needs to contain all of the information necessary for the completion of the foreseen processes relating to the object or system in a systematic, clear and simple way. It is not possible to unambiguously determine the scope and form of the technical documentation for all cases. In creating the technical documentation one should aim for optimal minimization of human work and scope of documentation. The documentation is developed by monitoring the development of the object or system from the concept stage through construction and maintenance. That is why the contents and the purpose of the documentation changes.

\section{Problem statement}

The lack of either legal or professional standards for the creation of the parts list / legend leaves room for creativity, so the look of the parts list / legend changes from company to designer, office or project. 
Research has been carried out to determine whether there is a significant impact on the intelligibility and identification of the drawing's content based on the form or type of the legend, because of the lack of regulations regarding the form and contents of the parts list / legend, and its wide use in different fields, and by various individuals who use the parts list / legend to describe and understand the laid out content, maps, plans etc.

In understanding the landscape architecture plan we rely on two elements. The first one is the mark identifying the location on the drawing, and the second element is a symbol in the legend which enables the association with the location identified by the mark, linking it with the appropriate new information. The creator of the drawing defines the symbols and links them with the information using a well-structured system of textual marks in the process of creating and organizing the drawing [8]. The main goal of the parts list / legend's designer is to organize and display a good description of the drawing in question in a clear and unambiguous way, so that the observer could come to the correct interpretation of the drawing in the quickest way possible.

The range of people who use the drawing is very large. One category is comprised of those who have to know how to read and create technical drawings, while the others just need to know how to read a drawing. In engineering, construction, architecture, design and styling there are almost no examples in which a drawing is not necessary. Because of the great variety there is no defined classification of drawings, instead they can be classified based on their starting points, e.g. contents, purpose, manner of rendering, drawing technique.

The rules of legend design are based on the basic principles of human perception. People perceive an object first, and then create the so called schemata in their mind, a mental structure that stores malleable knowledge on the environment, as well as individual, personal knowledge. The schemata include personal assumptions, expectations and plans. Based on the perceived information from the legend (the object of observation), the schemata is being constantly updated. The user learns and gains new information [9].

The importance of the elements of visualization is found in the functionality as a primary characteristic of the legend / parts list design, since it provides contextual information necessary for the interpretation of the content / data.

The legend / parts list represents a separate unit and thus should be intelligible even without the drawing, which is where its design value lies.

Interpretation, which includes the understanding of every information presented in the drawing, is dependent on the perception of the observer, his interest, as well as his personal potential and education.

Spatial perception is of great importance in the success of graphic education, and is a component of human intelligence which can be bettered through practice and education. Creativity and communication, which are the basis of graphic design, can be developed by an advanced and well-balanced programme based on research results in the multidisciplinary field. In educating graphic design engineers, a lot of importance should be put on developing their abilities of perception along with computer technology trends and the development of tools and techniques, which would result in a basis for the creation of a holistic engineer education whose education includes graphic design [5]. Since professors foster their students' development from beginners to expert engineers, it is important that their progress includes the acquisition of professional skills, as well as the encouragement for creative thinking, necessary for the development of innovative ideas [10].

Research has shown that it is necessary to adapt specific technologic education programmes into an allencompassing section that integrates aspects of national policy documents in the planned education programme [11]. In accordance with that, research in a field lacking certain guidelines would potentially be significant in creating guidelines that would in practice benefit all users and in developing educational disciplines dealing with graphic design of plans and documents on a national level.

In this case study, we tested the impact of selecting the symbols that describe the drawing; does it affect the accuracy and speed of interpreting the displayed content, and is it possible to impact the interpretation and reduce the mistakes that arise from reading the drawing by the selection of the symbols? By studying these kinds of systems it is possible to conclude which systems are more intelligible and form a basis for more complex systems that could be used in the future. An optimal variant could then be implemented into designing and planning syllabuses.

Designing the parts list / legend by inserting plan elements into the parts list / legend, the user will have an optimal way of reaching the correct interpretation of the information, while the appearance of content being described does not change [12]. Other styles, e.g. numbers, strokes from the legend, provide a new layer of information to the plan, enlarge the quantity of information, affect the look of the plan, intelligibility and noticeability of the information.

Using a simpler design solution for the parts list, which does not provide a new layer of information to the plan, enables a simpler interpretation of the data. The legend design style affects the speed of connecting data presented in the landscape architecture plan. The speed in which one chooses the correct symbol description in the legend does not necessarily mean it will be correctly interpreted, which is the primary role of a parts list / legend [13].

It is necessary to test in what ways different variants of parts list/legend designs impact the simplicity of using a landscape architecture plan. On the basis of that research, it would be possible to conclude which variant enables the easiest use and, thus, suggest it as an optimal solution for legend design in landscape architecture planning systems.

On the basis of the results gained in the research and for the purpose of easier learning, the optimal solution could be presented to students of landscape architecture, architecture, design and students of professions that use maps and plans as a guideline in developing designs that include describing and reading designs using a legend. The results could also benefit professors of design and landscape design, who use legends to describe proposed 
plans. Finally, the optimal design will enable the end user to more easily navigate and recognize the depicted situation.

That is the reason that this case study is concerned with legend design as a potential key factor influencing the effectiveness and intelligibility of a landscape architecture plan.

This case study explores the impact of legend design choice on a specific sample of plans and legends, often used in class exercises, chosen by experts in the field of landscape architecture. The objects of study were the symbols used in educating future experts that will be working on planning and designing plans. The purpose of researching engineering design is to develop new tools and methods, and guidelines for possible standards that would benefit the industry, modernize engineering education, evolve the curriculum and benefit future experts [14].

\section{Methodology}

Different students can interpret/define the ability to understand graphic information in different ways, based on their personal characteristics and preferences. That is why students' assessment of legend effectiveness can be subject to numerous influences that are hard to control and organize. To avoid subjectivity of the results, this case study employed eye-tracking technology which enables the collection of objective data on the way visual content is perceived. For the purpose of this study, visual content comprehension was measured based on the number of seconds and fixations needed to find the right information.

\subsection{The participants}

Our aim was to include in the study participants educated in the same field, which they were still not fully familiar with, since the goal of the study was to test how different legends impact the perception of new information in the process of learning. A group of students from the University of Zagreb - Faculty of Agriculture was chosen to participate in the study. During the study, the participants were enrolled in the first semester of Landscape Architecture. The study included 50 participants from 19 to 20 years old. The mean age of the participants was $19,46(S D=0,50) .50 \%$ of the participants were women, and $50 \%$ were men. All participants had good eyesight, and those that wore glasses or contact lenses had them on during the experiment. All of the participants passed to Ishihara Color Vision test, and it was concluded that they all had the ability to differentiate colours.

\subsection{Samples}

We used three samples that all represented the same fictitious planting plan presented on a ground plan. The samples only varied in the way in which different plant names were represented. The planting plan was shown in black colour using marks for vegetation that are common in the profession. The first sample contained the planting plan and a classic legend, in which the name of the plant was accompanied with the same graphical symbol that represented the plant on the plan. The second sample contained the planting plan and a numeric legend. In this type of legend, each number was accompanied by a corresponding plant name. To connect the name of the plant with its graphic representation on the planting plan, the corresponding numbers were inserted into the planting plan, so that each plant was shown having a number as well. The third sample did not contain a legend. Instead the names of the plants were marked by lines. The starting point of each of the lines was on the represented plant, and the ending point exited the frame of the plan and pointed to the corresponding plant name. All of the samples are shown in Fig. 1. The text on all of the samples was written in Arial font, size 14 px. The samples were designed using Adobe Illustrator CS3.

\subsection{Equipment}

The samples were shown on Lenovo monitors (model LEN L1900pA) with the resolution set to $1280 \times 1024$ and a $60 \mathrm{~Hz}$ refresh rate. The samples were observed from a distance of $60 \mathrm{~cm}$. The participants reactions, which were used to determine the time needed to find the correct information, were measured with a standard PC mouse. Eye movement, needed to determine the number of fixations needed to notice the information, was measured with Tobii Eye Tracker X60. Tobii Studio 3.2.1. was used as software support to carry out the testing.

\subsection{The procedure}

The participants were placed in front of the monitor in a separate room without additional lighting. At the beginning of each experiment, the task was explained to the participants using an example planting plan shown on the monitor. After the example, one of the planting plans was shown on the monitor for two seconds, after which a red arrow was shown for one second. The role of the arrow was to point to one of the plants shown on the planting plan. The task of the participants was to find the name of the plant and click on it. There was no time limit. The participants were informed of the importance of answering correctly. After the click, the participants were shown a blank screen. When they were ready, they were shown the second sample of the planting plan and the accompanying legend. The same procedure as with the previous sample followed. The order in which the samples were shown was different for each participant. Subsequent analysis determined that the order did not have an effect on the participants' reactions. The time needed to spot the wanted information was measured during the experiment. The time was measured in seconds, from the moment the red arrow disappeared to the moment when the participant clicked on one of the answers (the name of the plant). The number of fixations needed to find the name of the plant was also measured. All fixations that lasted a minimum of $60 \mathrm{~ms}$ were included in the analysis. The fixation radius was $50 \mathrm{px}$. 


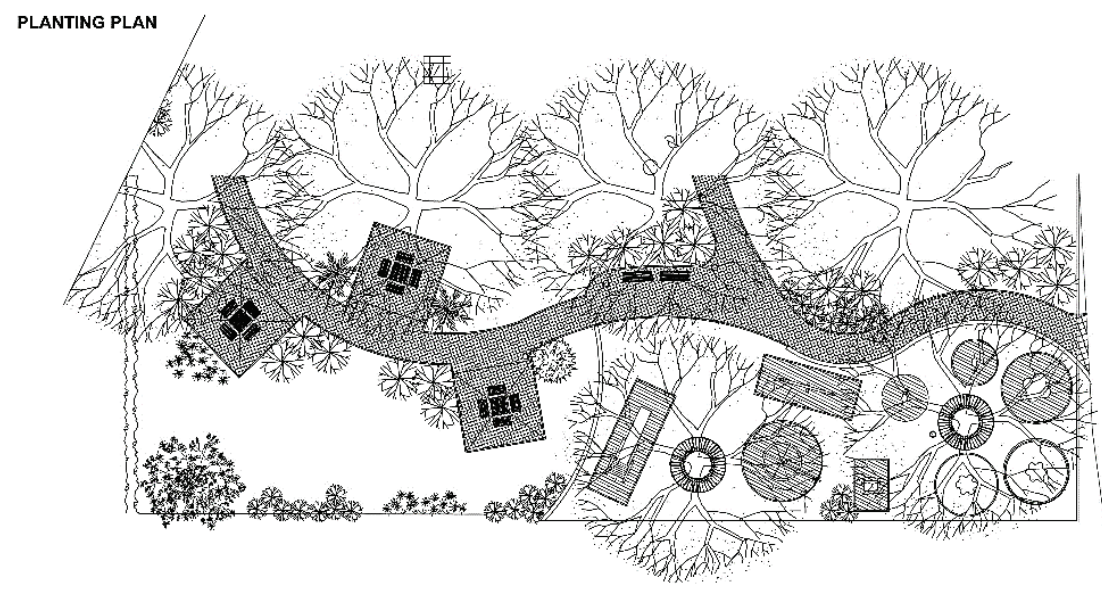

\begin{tabular}{|c|c|c|c|c|c|}
\hline \multicolumn{6}{|l|}{ LEGEND } \\
\hline manim & $\begin{array}{l}\text { Carpinus betulus } \\
\text { (Hombeam) }\end{array}$ & 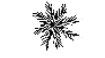 & $\begin{array}{l}\text { Catalpa bignoides } \\
\text { (Catalpa) }\end{array}$ & 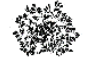 & $\begin{array}{l}\text { Tamarix tetrandra } \\
\text { (Tamaris) }\end{array}$ \\
\hline 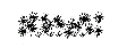 & $\begin{array}{l}\text { Rosmarinus Officinalis } \\
\text { (Rosemary) }\end{array}$ & 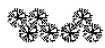 & $\begin{array}{l}\text { Lavandula angustifolia } \\
\text { (Lavender) }\end{array}$ & & \\
\hline 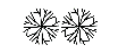 & $\begin{array}{l}\text { Kerria japonica - } \\
\text { Golden Guinea (Keria) }\end{array}$ & 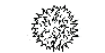 & $\begin{array}{l}\text { Pinus nigra "Brepo" } \\
\text { (Dwarf pine) }\end{array}$ & & \\
\hline
\end{tabular}

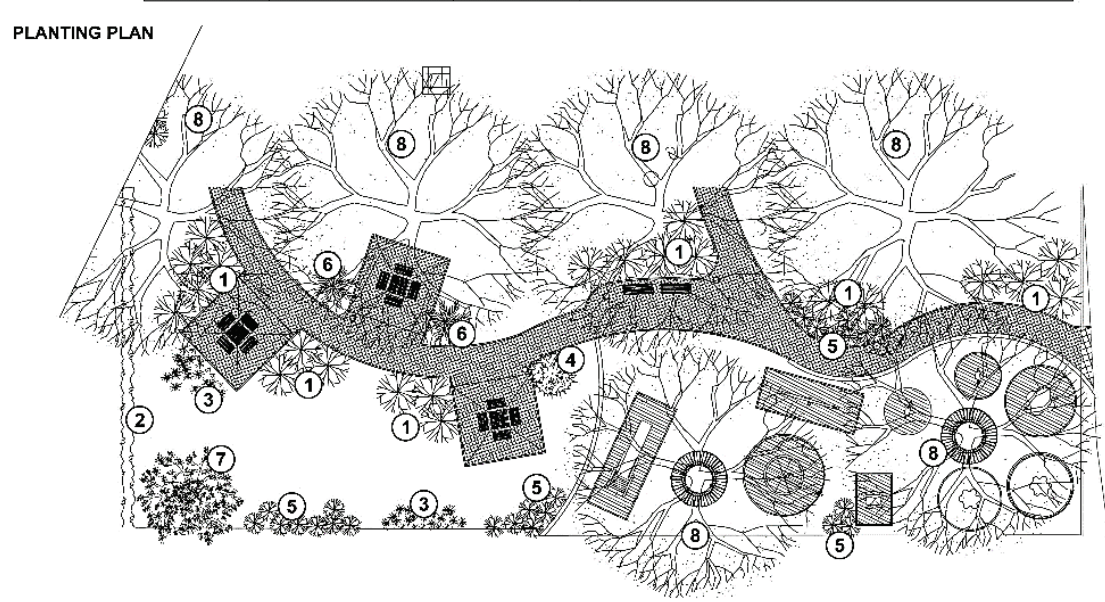

\begin{tabular}{|c|c|c|c|c|c|c|c|}
\hline \multicolumn{8}{|c|}{ LEGEND } \\
\hline 1 & $\begin{array}{l}\text { Kerria japonica - } \\
\text { Golden Guinea (Keria) }\end{array}$ & 3 & $\begin{array}{l}\text { Rosmarinus Officinalis } \\
\text { (Rosemary) }\end{array}$ & 5 & $\begin{array}{l}\text { Lavandula angustifolia } \\
\text { (Lavender) }\end{array}$ & 7 & $\begin{array}{l}\text { Tamarix tetrandra } \\
\text { (Tamaris) }\end{array}$ \\
\hline 2 & $\begin{array}{l}\text { Carpinus betulus } \\
\text { (Hornbeam) }\end{array}$ & 4 & $\begin{array}{l}\text { Pinus nigra "Brepo" } \\
\text { (Dwarf pine) }\end{array}$ & 6 & $\begin{array}{l}\text { Catalpa bignoides } \\
\text { (Catalpa) }\end{array}$ & 8 & $\begin{array}{l}\text { Fraxinus excelsior } \\
\text { (Ash tree) }\end{array}$ \\
\hline
\end{tabular}

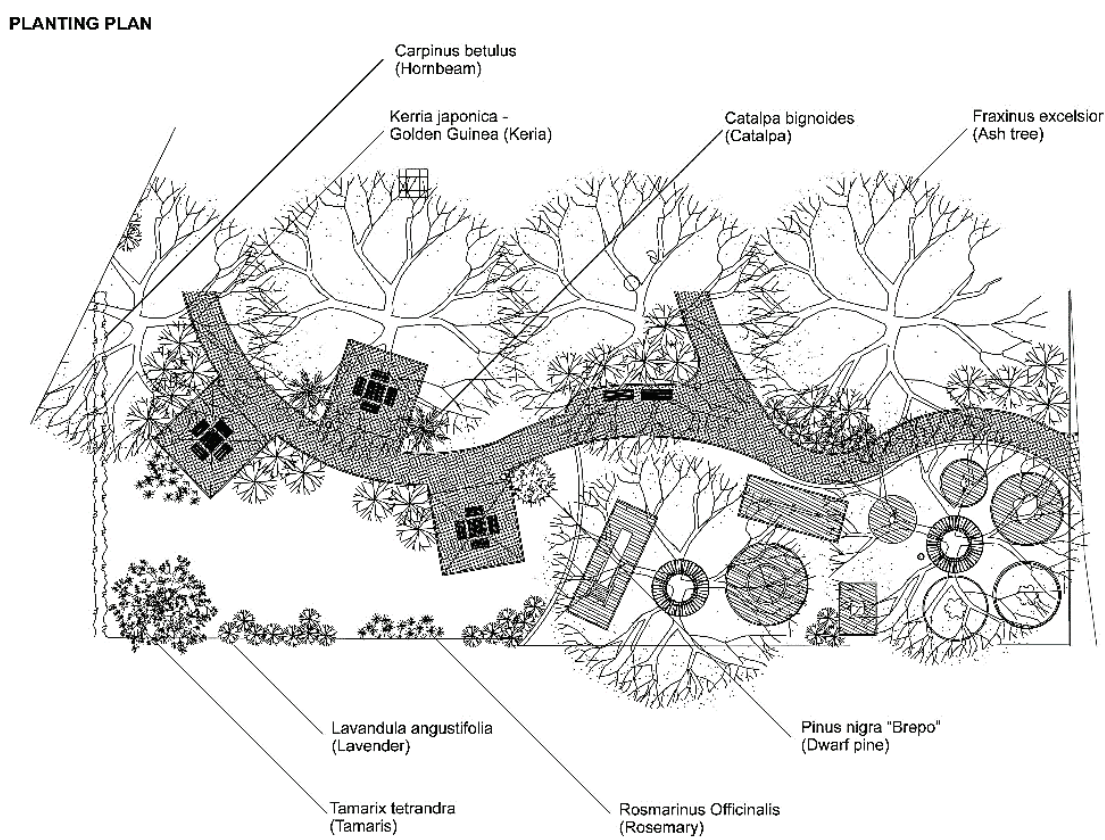

Figure 1 Sample overview; $1^{\text {st }}$ sample - classic legend, $2^{\text {nd }}$ sample - numeric, $3^{\text {rd }}$ sample - lines 


\section{Results and discussion \\ 4.1 Correctly perceived information}

The statistical analysis was carried out based on the data received from each participant. Two eye-tracking results were disqualified from the analysis because the participants did not understand the task. The percentage of correct answers showed that the participants made the least mistakes in perceiving the correct information when using numerical markings (6\% of incorrect answers). They erred more when they were searching for the correct information using lines (12\% of incorrect answers), and the highest number of incorrect answers was recorded when the participants used the classic legend type (16\% of incorrect answers). The continuation of the analysis included only data from those participants that gave correct answers.

\subsection{Statistical methods}

The Friedman test was used to determine the statistically significant difference (at a 0,05 level) in time needed to perceive the information on different samples. After that, the Wilcoxon test was run to determine which samples differ from each other. The level of significance was corrected using the Bonferroni correction method, and it was set at a 0,0167 level. The same statistical methods were used to analyse the number of fixations needed to perceive the correct information.

\subsection{Information perception time}

There is a statistically significant difference in the time needed to perceive information using differently designed legends $\left(\chi^{2}(2)=9,67, p<0,05\right)$. The results show no difference in the speed of perception when the information is displayed in the form of a classic or numeric legend $(Z=-1,328, r=-0,14)$. However, the time needed to perceive information increases significantly when using lines to search for it, compared to using a classic legend $(Z=-3,955, r=-0,43)$ or a numeric legend $(Z=-2,606, r=-0,27)$. Fig. 2 shows a box plot graph with the stated results.

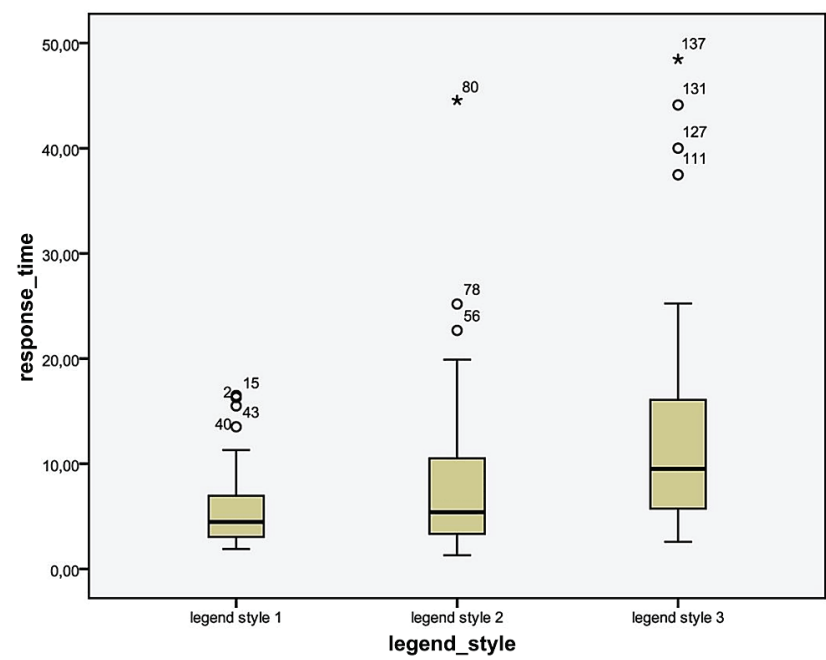

Figure 2 Box plot graph illustrating the time (in seconds) needed to perceive information

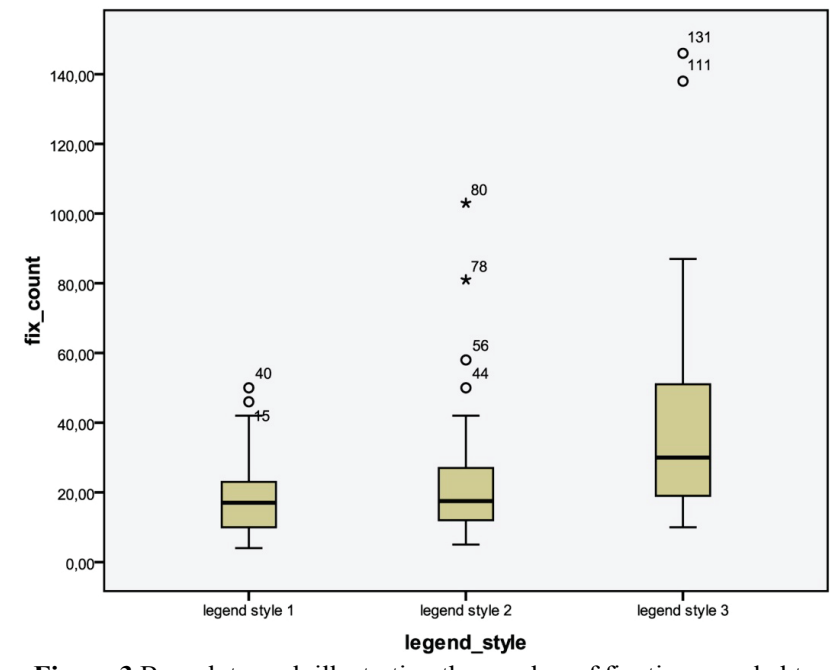

Figure 3 Box plot graph illustrating the number of fixations needed to perceive information

\subsection{Number of fixations needed to perceive the information}

There is a statistically significant difference in the number of fixations needed to perceive the right information using differently designed legends $\left(\chi^{2}(2)=\right.$ $14,69, p<0,05)$. The Wilcoxon test showed no difference in the number of fixations needed to perceive the information when the information is displayed in the form of a classic or numeric legend $(Z=-1,191, r=-0,13)$. However, a greater number of fixations is needed to perceive the information using lines as opposed to using a classic legend $(Z=-3,822, r=-0,41)$ or a numeric legend $(Z=-2,983, r=-0,31)$. Fig. 3 shows a box plot graph with the stated results.

This case study had a few limitations. A landscape architecture plan was used and may, thus, not be applicable to other engineering fields. When considering the development of an automated elaboration procedure for a certain type of plans within the research, one that would be the result of scientific analysis, it was found that the plans were a professionally directed, structured representation of knowledge and as such have their own logic and include a cognitive process. This logic can be understood using knowledge from the scientific field in question and applied for the automated process of plan design. The "knowledge system" is used for the process itself and the results of the scientific analysis, while plans represent the structure in visual form, but the problem is that only a small number of people, that are not familiar with this scientific field, can understand a "knowledge system" presented in this fashion [15]. Cognitive style, which depends on a person's cognitive structure, and spatial experience are factors that influence the design process. Authors usually rely on their experience in solving spatial problems and use information relating to their past experiences when creating new concepts, planning and solving design problems [16].The results of this empirical study show which information is optimal for designer - client, and designer - collaborator communication. If such information is acquired at university, they become a part of students' experience and, subsequently, their cognitive style, with the added value based on the results of the study. This encompasses the cognitive style results and personal value systems, 
which is very important for the development of the curriculum within the multidisciplinary field of landscape architecture, architecture and design, where it is especially important to abide by both factors [17]. Landscape architecture plan design style could also influence interpretation, and as such might not be applicable to all engineering fields. This could be determined by carrying out testing on multiple groups from different professional fields. Choosing three legends presents a typological limitation and a risk for a possible absence of the optimal legend choice. Science and technology ensure that the facts presented in the plan are correct and valid. Freedom of design represents a contribution to technology, enables a richer expression of cartographic content and includes a warm human component, that is, the soul of the artist who has left his mark on a plan. Different approaches to map design can have different effects on the users. Some might like one mode of information presentation more than the other and that might affect their interpretation and, consequently, the results of the research [18]. The landscape architecture plan, designed for this study, as well as the three types of legends, were presented in black colour, therefore there is a possibility that a presentation in colour might have influenced the results of the study. Choosing the right symbols depends on the nature of the phenomena being depicted on the map, and the purpose of the map. When using colour to differentiate between elements on a map, one should take into consideration that systems designed in that manner will be hard to understand without a legend. Colour range does not have a logical order for the observer. Knowledge of colour characteristics is essential for choosing the right colour, because colour perception in maps is influenced by graphic logic, visual perception, and even the observer's cultural aspects. These criteria represent a type of added risk in researches that use colour in their samples [19]. The fact that every author can design their own legend justifies the choice of sample and background. Plans leave a strong visual impression that is why incorrect design technique can lead to incorrect interpretation of the intended message. The quality of a plan can be judged by how well and how efficiently it communicates with the user, as well as by the messages it carries. The quantity of information that we insert into a plan from a legend can also present a risk in carrying out the study and to the quality of the results. By increasing the number of symbols, which happens with numeric legends and lines, the quantity of symbols and information changes the appearance of the plan, and can lead to congestion and impaired visual differentiation of the data. It is hard to predict educational development trends in the field of technology, but it is possible to try and provide guidelines, summaries of the positive and/or negative factors, as a database for experts included in the development of the curriculum. It is extremely important to understand the way in which students learn, take into consideration different modes of learning with a goal for easier acquisition of knowledge, and coordinate this with a new curriculum [20]. Global changes demand a transformation of the education system which plays a great role in securing opportunities for future experts [21]. It is necessary that courses evolve in line with economic, political, social and cultural changes for the development of the curriculum that best prepares students for future employment and provides them with the needed skills for their future occupation [22]. The development of a curriculum that follows, not only the standardized design experience, but also its function and product message, creates a connection among science, technology, society and the individual as integral factors of the project [23].

\section{Conclusion}

During every step of map design it is not only necessary to take into account the intended message, but it is also important to consider the user to whom this message is intended. The conclusions and interpretations taken from this study cannot be generalized to the whole public. Given the nature of the study, the chosen sample is optimal because it captures a small segment of the population defined by a common characteristic (in this case, all of the participants are experts in creating design products, potential clients, consequently representing potential users of graphic horticulture solutions), which makes it homogenous. This choice is also optimal because of the specific equipment used for the study, because using the same space for research enables control over external variables, and the same exposure of the participants to potential influences of external factors on the course of the study (e.g. light, temperature, silence etc.). Another advantage of this sample is its costeffectiveness and easy implementation. Regardless of the fact that we are dealing with a homorganic population, generalization to the whole population would not be justified, because the sample is not representative. However, it is possible to come to certain conclusions regarding graphically designed legends on the basis of statistical analysis using the Friedman and Wilcoxon tests, and apply them in the teaching process. The results of the study confirm that legend design style impacts the speed of reading and finding the correct information. Subsequently, the hypotheses put forth are accepted. The classic legend type has the biggest negative effect on finding the correct information. The basic reason for that is probably the similarity between forms shown in the legend frame, which leads to mistakes in the precision while differentiating among different plant species. On the other hand, numeric legends have a positive effect on finding the correct information, since numeric symbols are easier to tell apart, not only because of their simple form, but also because of their symbolic meaning which is familiar to the observers. However, when looking at the speed of information perception, results show that it is the same when using a classic or numeric legend. The linear solution has the biggest influence on the speed of perception, that it the system of displaying information using lines. In those cases, the observers need more time to find the correct information in the planting plan. The linear structure used for indicating information presents the basic problem, but it also appears again in its monotone form in the design of the planting plan's content. This leads to an overlap of forms, additional visual load and slower response times in a cluster of similarly structured information. That is why it is recommended, in these kinds of situations, to use lines that are shaped in contrast with the elements displayed in 
the planting plan. That can be achieved using colour, the size or style of the lines. The designers have a chance to give the plan and legend, not just a functional, but also an aesthetic value during the design process, having in mind that form comes from function. When designing a legend, it is important to have in mind that the basic goal is to provide an additional explanation for the content presented on the plan and to provide the user with the most correct interpretation of the plan's content possible. The numeric legend has proven to be the optimal choice in this respect and can be recommended for inclusion in the syllabus for design and planning. In sense of design, its lack lies in the possible diminishing of the aesthetic value of the plan which changes with the introduction of a new layer of information. The numeric legend type could prove to be the most acceptable choice for experts and the general public, i.e. the users, because of its well-known symbols.

The guidelines for graphic design taken from this study are: Students best perceive the numeric legend which we recommend including as an example of good practice for the correct interpretation of a project. That would make it easier for students to perceive information and learn, the legend's function would be fulfilled and the users would correctly interpret the design. The classic legend type and the legend using lines could be presented to students as an example that does not fulfil the legend's function in a satisfactory manner, considering the amount of incorrect answers. This case study is a good example of what impact information visualization has on simple and correct identification and understanding of the landscape architecture plan content in question, the results of which represent a basis for further development of the engineering curricula.

\section{References}

[1] Aničić, B. (ed). Jubilarni zbornik 40 godina studija krajobrazne arhitekture. Zavod za krajobraznu arhitekturu. Zagreb : Agronomski fakultet Sveučilišta u Zagrebu, 2008.

[2] Hrvatska komora arhitekata. Pravilnici: Projekti

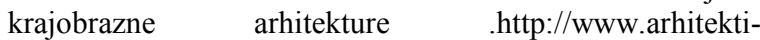
hka.hr/hr/komora/akti-komore/pravilnici/pravilnik-ocijenama-usluga/projekti-krajobrazne-arhitekture/ (25.11.2013).

[3] Kangas, K.; Seitamaa-Hakkarainen, P.; Hakkarainen, K. Design expert's participation in elementary students' collaborative design process. // International Journal of Technology and Design Education. 23, 2(2013), pp. 161178. DOI: $10.1007 / \mathrm{s} 10798-011-9172-6$

[4] Kljajin, M.; Opalić, M. Inženjerska grafika: Grafička komunikacija u tehnici. Slavonski Brod: Strojarski fakultet u Slavonskom Brodu, 2010.

[5] Marunić, G.; Glazar, V. Spatial ability through engineering graphics education. // International Journal of Technology and Design Education. 23, 3(2013), pp. 703-715. DOl: 10.1007/s10798-012-9211-y

[6] Nikolić, D. Tehničko crtanje i deskriptiva. Zagreb: Viša grafička škola Zagreb, 1986.

[7] Opalić, M.; Kljajin, M.; Sebastijanović, S. Tehničko crtanje - Sveučilišni udžbenik. Slavonski Brod: Strojarski fakultet u Slavonskom Brodu, 2003.

[8] Celentano, A.; Pittarello, F. From real to metaphoric maps: Cartography as a visual language for organizing and sharing knowledge. // Journal of Visual Languages \&
Computing. 23, 2(2012), pp. 63-77. DOl: 10.1016/j.jvlc.2011.11.004

[9] Buziek, G. Legend designs for noninteractive cartographic animations. // Computers \& Geosciences. 26, 1(2000), pp. 21-28. DOI: 10.1016/S0098-3004(99)00029-1

[10] Gómez Puente, S. M.; Eijck, M.; van, Jochems, W. A sampled literature review of design-based learning approaches: a search for key characteristics. // International Journal of Technology and Design Education. 23, 3(2012), pp. 717-732. DOI: 10.1007/s10798-012-9212-x

[11] Potgieter, C. Linking learning activities and assessment activities to learning outcomes and assessment standards when teaching technology: a case study. // International Journal of Technology and Design Education. 23, 4(2013), pp. 969-986. DOI: 10.1007/s10798-012-9226-4

[12] Zikmund-Fisher, B. J.; Fagerlin, A.; Ubel, P. A. A Demonstration of "Less Can Be More" in Risk Graphics. // Medical Decision Making. 30, 6(2010), pp. 661-671. DOI: 10.1177/0272989X10364244

[13] Talbot, J.; Lin, S.; Hanrahan, P. An Extension of Wilkinson's Algorithm for Positioning Tick Labels on Axes. // IEEE Transactions on visualization and computer graphics. 16, (2010), pp. 1036-1043. DOI: 10.1109/TVCG.2010.130

[14] Miller, W. S.; Summers, J. D. Investigating the use of design methods by capstone design students at Clemson University. // International Journal of Technology and Design Education. 23, 4(2013), pp. 1079-1091. DOI: 10.1007/s10798-012-9227-3

[15] Bui, E. N. Soil survey as a knowledge system. // Geoderma, 120, 1-2(2004), pp. 17-26. DOl: 10.1016/j.geoderma.2003.07.006

[16] Yazici, Y. E. Effects of spatial experiences \& cognitive styles in the solution process of space-based design problems in the first year of architectural design education. // International Journal of Technology and Design Education. 23, 4(2013), pp. 1005-1015. DOl: 10.1007/s10798-012-9220-x

[17] Savic, M. Kashef, M. Learning outcomes in affective domain within contemporary architectural curricula. // International Journal of Technology and Design Education. 23, 4(2013), pp. 987-1004. DOI: 10.1007/s10798-013-9238-8

[18] Cartwright, W. E. Addressing the value of art in cartographic communication. // ISPRS Journal of Photogrammetry and Remote Sensing. 65, 3(2010), pp. 294-299. DOI: 10.1016/j.isprsjprs.2010.01.004

[19] Bartels, C. J.; van, Beurden, A. U. C. J. Using geographic and cartographic principles for environmental assessment and risk mapping. // Journal of Hazardous Materials. 61, 13(1998), pp. 115-124. DOI:10.1016/S0304-3894(98)00115-0

[20] Williams, P. J. Research in technology education: looking back to move forward. // International Journal of Technology and Design Education. 23, 1(2013), pp. 1-9. DOI: 10.1007/s10798-011-9170-8

[21] Pavlova, M. Teaching and learning for sustainable development: ESD research in technology education. // International Journal of Technology and Design Education. 23, 3(2013), pp. 733-748. DOI: 10.1007/s10798-012-9213-9

[22] Mativo, J. M.; Myra, N.; Womble, M. N.; Jones, K. H. Engineering and technology students' perceptions of courses. // International Journal of Technology and Design Education. 23, 1(2013), pp. 103-115. DOI: 10.1007/s10798011-9167-3

[23] Vries, M. J. de. Technology and Society: a Methodological Perspective. // International Journal of Technology and Design Education. 7, 1-2(1997), pp. 21-32. 
Authors' addresses

Ivana Žganjar, MSc International Relation's Coordinator, PhD student

University of Zagreb, Faculty of Graphic Arts,

Getaldiceva 2, 10000 Zagreb, Croatia

E-mail: ivana.zganjar@grf.hr

Dorotea Kovačević 2, MSc Assistant, PhD student

University of Zagreb, Faculty of Graphic Arts,

Getaldiceva 2, 10000 Zagreb, Croatia

E-mail: dorotea.kovacevic@grf.hr

Maja Brozović, PhD Associate Professor

University of Zagreb, Faculty of Graphic Arts,

Getaldiceva 2, 10000 Zagreb, Croatia

E-mail: maja.brozovic@grf.hr 